\title{
A Historical Perspective of Economic and Financial Stability in South East Europe
}

\author{
Eglantina Hysa \\ Lecturer at Economics Department, Epoka University, \\ ehysa@epoka.edu.al \\ Mergleda Hodo \\ Research Assistant at Banking and Finance Department, Epoka University, \\ mhodo@epoka.edu.al
}

\section{Doi:10.5901/ajis.2013.v2n9p706}

\begin{abstract}
The paper offers a general overview of situation during the two crises, Great Depression and Great Recession for some of the South East European countries. It studies the linkage between financial issues and economic development by making a comparison of two periods. This paper provides a review of the theory behind the ties of these two components and the channels they affect each other. Both crises have had deteriorate effects in the SEE countries but often this group of countries have had symmetric hits, which leads to the idea of acting as a common region. As a main recommendation we emphasize the collaboration of countries by making similar reforms and moving together in standards achievement to the process of being part of $E U$, if it remains to be an objective, or constituting a "uniform" and compact competitive region.
\end{abstract}

Keywords: Banking, Economic Growth, South East European Countries

\section{Introduction}

There is a consensus among economists that financial development effects positively the economic growth. Theoretically, there are two channels of how financial development enable growth; the first one is through a supply leading (financial development spurs growth) and the second one is through a demand following (growth generates demand for financial products) channel. The relationship between financial development and economic growth is a debate which has its initial point in the $18^{\text {th }}$ century. A lot authors such as Walter Bagehot (1873), Joseph Schumpeter (1912), John Hicks (1969) and Merton Miller (1988) stated that finance plays an important role in growth and development.

This first focus of this study is the identification of literature related to the relationship between the financial development and economic growth. According to the literature, the authors are divided into two main groups, some of them think that the financial development is an important engine of the economic growth and the others think that economic growth is a kind of motor which foster the further development of financial sector. The second focus of this study is the identification of this relationship in the South East Europe during two difficult periods, the great depression and the great recession. As known, the effects of these two periods (crises) have been evident in almost all the countries, but our analysis is limited in just the SEE countries.

\section{Literature Review}

Financial development involves improvements in producing information about possible investments and allocating capital, monitoring firms and exerting corporate governance, trading/ diversification/ and management of risk, mobilization and pooling of savings and easing the exchange of goods and services. These five economic components have been analyzed from different authors in different years by taking into consideration diverse channel. Tridip Ray has made a review of authors dealing with the relationship between financial development and economic growth as in the below table. 
Table 1: Financial Development and Economic Growth: A Review of Literature

\begin{tabular}{|c|c|c|}
\hline $\begin{array}{l}\text { Economic Factors } \\
\text { improved by Financial } \\
\text { Development }\end{array}$ & Authors (year) & Specifications \\
\hline \multirow[t]{2}{*}{$\begin{array}{l}\text { 1.Producing information } \\
\text { about possible } \\
\text { investments and } \\
\text { allocating capital. }\end{array}$} & $\begin{array}{l}\text { - Ramakrishnan and Thakor, 1984; Boyd and } \\
\text { Prescott, 1986; Allen, 1990; Greenwood and } \\
\text { Jovanovic, 1990; King and Levine, 1993; } \\
\text { Kashyap, Stein and Rajan, 1998. }\end{array}$ & $\begin{array}{l}\text { - Financial intermediaries undertake the costly } \\
\text { process of researching investment possibilities for } \\
\text { others }\end{array}$ \\
\hline & $\begin{array}{l}\text { - Grossman and Stiglitz, 1980; Kyle, 1984; } \\
\text { Merton, 1987; Holmstrom and Tirole, } 1993 .\end{array}$ & $\begin{array}{l}\text { - Stock markets may stimulate the production of } \\
\text { information about firms. }\end{array}$ \\
\hline \multirow{5}{*}{$\begin{array}{l}\text { 2. Monitoring firms and } \\
\text { exerting corporate } \\
\text { governance. }\end{array}$} & $\begin{array}{l}\text { - Coase, 1937; Jensen and Meckling, 1976; } \\
\text { Fama and Jensen, 1983; Myers and Majluf, } \\
1984 .\end{array}$ & $\begin{array}{l}\text { - How equity and debt holders influence managers } \\
\text { to act in the best interest of the providers of capital }\end{array}$ \\
\hline & - Shliefer and Vishny, 1997. & $\begin{array}{l}\text { - Information asymmetries may keep diffuse } \\
\text { shareholders from effectively exerting corporate } \\
\text { governance }\end{array}$ \\
\hline & $\begin{array}{l}\text { - Townsend, 1979; Gale and Hellwig, 1985; } \\
\text { Boyd and Smith, } 1994 .\end{array}$ & $\begin{array}{l}\text { - An extensive literature demonstrates how debt } \\
\text { contracts may arise to lower the costs of } \\
\text { monitoring firm insiders }\end{array}$ \\
\hline & - Aghion, Dewatripont and Rey (1999) & $\begin{array}{l}\text { - Link the use of debt contracts to growth through } \\
\text { adoption of new technologies. }\end{array}$ \\
\hline & $\begin{array}{l}\text { - Diamond, 1984; Bencivenga and Smith, } \\
\text { 1993; de la Fuente and Marin, 1996; Gurley } \\
\text { and Shaw, 1955; Patrick, 1966; Greenwood } \\
\text { and Jovanovic, 1990; Saint-Paul, 1992; } \\
\text { Devereux and Smith, 1994; Obstfeld, 1994; } \\
\text { Acemoglu and Zilibotti, 1997. }\end{array}$ & $\begin{array}{l}\text { - Financial intermediaries improve corporate } \\
\text { governance. }\end{array}$ \\
\hline \multirow{8}{*}{$\begin{array}{l}\text { 3.Trading, diversification, } \\
\text { and management of risk. }\end{array}$} & - Greenwood and Jovanovic, 1990. & $\begin{array}{l}\text { - Intermediaries improve resource allocation and } \\
\text { foster growth. }\end{array}$ \\
\hline & - Acemoglu and Zilibotti, 1997. & $\begin{array}{l}\text { - Financial systems allow agents to hold a } \\
\text { diversified portfolio of risky projects } \\
\text { - Risks that cannot be diversified at a particular } \\
\text { point of time (e.g., macroeconomic shocks), can } \\
\text { be diversified across generations. }\end{array}$ \\
\hline & - Allen and Gale, 1997. & $\begin{array}{l}\text { - Liquidity risk arises due to uncertainties } \\
\text { associated with converting assets into a medium of } \\
\text { exchange. }\end{array}$ \\
\hline & - Hicks, 1969. & $\begin{array}{l}\text { - Industrial revolution required a financial } \\
\text { revolution. }\end{array}$ \\
\hline & - Diamond and Dybvig, 1983. & $\begin{array}{l}\text { - Savers choose between an illiquid, high-return } \\
\text { project and a liquid, low-return project. }\end{array}$ \\
\hline & - Levine, 1991. & $\begin{array}{l}\text { - Takes the Diamond-Dybvig set-up; } \\
\text { - Models the endogenous formation of equity } \\
\text { markets; links this to a growth model. }\end{array}$ \\
\hline & - Bencivenga, Smith and Starr, 1995. & $\begin{array}{l}- \text { - Financial markets lower trading costs } \rightarrow \\
\text { increase liquidity } \rightarrow \text { induce a shift to long- } \\
\text { gestation, high return technologies. }\end{array}$ \\
\hline & - Bencivenga and Smith, 1991. & $\begin{array}{l}\text { - Financial intermediaries eliminate liquidity risks } \\
\rightarrow \text { increase investment in high-return, illiquid } \\
\text { assets } \rightarrow \text { accelerate growth. }\end{array}$ \\
\hline $\begin{array}{l}\text { 4. Mobilization and } \\
\text { pooling of savings. }\end{array}$ & & $\begin{array}{l}\text { - Mobilization is the costly process of } \\
\text { agglomerating capital from disparate savers to } \\
\text { investors. }\end{array}$ \\
\hline $\begin{array}{l}\text { 5. Easing the exchange } \\
\text { of goods and services. }\end{array}$ & - Greenwood and Smith, 1997. & $\begin{array}{l}\text { - Financial arrangements that lower transaction } \\
\text { costs can promote specialization, technological } \\
\text { innovation and growth. }\end{array}$ \\
\hline
\end{tabular}

Source: Tridip Ray, Financial Development and Economic Growth: A Review of Literature 
Financial instruments, markets, and institutions arise to ameliorate the effects of information, enforcement, and transactions costs, which have a direct impact in the savings rates, investment decisions, technological innovations and steady-state growth rates. But, from another point of view, changes in economic activity too can influence financial systems with dynamic implications for economic growth. The effects from financial development to economic growth and from economic growth to financial development can be defined to be a vicious cycle.

\section{Economic Crisis during 1929-1933 for SEE}

The overall states and countries were affected by both crises. These global downturns affected also the South East Europe. Big changes were obvious in trade, industrial production, private consumption, inflation, FDI, commercial lending and government accounts. But it should be taken into consideration the period of 79 years between the crises which underline some significant differences in economic philosophy and policy. For example, the stock market in 2008 did not decrease as much as in 1929.

According to Robert J. Samuelson, (The Great Depression, Concise Encyclopedia of Economics), the depression can be understood only in the context of the times. There are four huge differences between then and now:

\subsection{The gold standard}

Most money was paper, as it is now, but governments were obligated, if requested, to redeem that paper for gold. This "convertibility" put an upper limit on the amount of paper currency governments could print, and thus prevented inflation. There was no tradition (as there is today) of continuous, modest inflation. Most countries went off the gold standard during World War I, and restoring it was a major postwar aim. Britain, for instance, returned to gold in 1925. Other countries backed their paper money not with gold, but with other currencies-mainly U.S. dollars and British poundsthat were convertible into gold. As a result flexibility of governments was limited. A loss of gold (or convertible currencies) often forced governments to raise interest rates. The higher interest rates discouraged conversion of interest-bearing deposits into gold and bolstered confidence that inflation would not break the commitment to gold.

\subsection{Economic policy}

Apart from the gold standard, economic policy barely existed. There was little belief that governments could, or should, prevent business slumps. These were seen as natural, therapeutic, and self-correcting. The lower wages and interest rates caused by slumps would spur recovery. The 1920-21 downturn (when industrial production fell 25 percent) had preceded the prosperous twenties. "People will work harder, live a more moral life," Andrew Mellon, Treasury secretary under President Herbert Hoover, said after the depression started. "Enterprising people will pick up the wrecks from less competent people," he claimed. One exception to the hands-off attitude was the Federal Reserve, created in 1913. It was charged with the responsibility for providing emergency funds to banks so that surprise withdrawals would not trigger bank runs and a financial panic.

\subsection{Production patterns}

Farming and raw materials were much more important parts of the economy than they are today. This meant that lower commodity prices could cripple domestic prosperity and world trade, because price declines destroyed the purchasing power of farmers and other primary producers (including entire nations). In 1929 farming accounted for 23 percent of U.S. employment (versus 2.5 percent today). Two-fifths of world trade was in farm products, another fifth in other raw materials. Poor countries (including countries in Latin America, Asia, and Central Europe) exported food and raw materials and imported manufactured goods from industrial nations.

\subsection{The impact of World War I}

Wartime inflation, when the gold standard had been suspended, raised prices and inspired fears that gold stocks were inadequate to provide backing for enlarged money supplies at the new, higher price level. This was one reason that convertible currencies, such as the dollar and pound, were used as gold substitutes. The war weakened Britain, left Germany with massive reparations payments, and split the Austro-Hungarian Empire into many countries. These countries, plus Germany, depended on foreign loans (in convertible currencies) to pay for their imports. The arrangement 
was unstable because any withdrawal of short-term loans would force the borrowing countries to retrench, which could cripple world trade.

The impacts of 1929 crisis are as follows:

- Unemployment increased significantly

- Gross national product declined

- General prices of goods fell dramatically

- Gold standard collapsed (governments tried to protect their reserves of gold by keeping interest rates high and credit tight for too long).

- Negative impact on credit, spending, and prices.

The incomes of neighbors and partner countries in trade fall significantly due to the fall in prices of primary products. The foreign debt payments became extremely difficult and by the end of 1931 countries like Poland, Romania, Yugoslavia and Bulgaria were in an untenable indebtedness. There were two main policies to overcome the negative effects of crisis, exchange controls and state intervention into the industrial and financial sector. These policies had significant deflationary effects on enterprises and a knock on effect on the financial and credit facilities.

\section{Economic Crisis during 2008-2010 for SEE}

The great depression affected deeply all the economy of SEE countries. The EU trade partners falled the demand for export which affected to lower industrial production, reducing private consumption inflation, FDI, commercial lending and government accounts.

\subsection{Trade}

During the recession period in 2007-2008 the export in all SEE countries has slowed dramatically almost $40 \%$ from January to July 2008. Trade has dropped in manufacturing export by5\% per month, furniture equipment, and in all important export industries for many SEE countries. Albania's export reduced demand in its largest trading partners. Bosnia and Herzegovina affected from the collapse in commodity prices while Croatian exports faced with the real effective appreciation of the kuna relative to the euro in 2008. Merchandise exports in 2008 have declined by $32.2 \%$ in the Former Yugoslav Republic of Macedonia but for 2009 it saw trade growth like Bulgaria and Romania.

Figura1. Total SEE Exports to EU-25

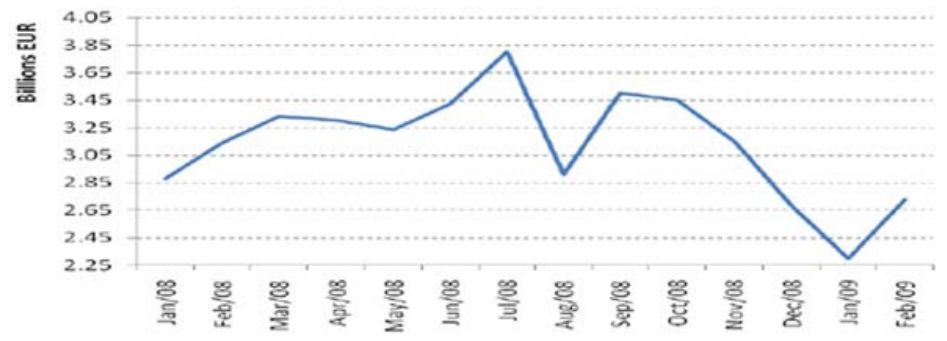

\subsection{Industrial production}

In the half of 2008 and early 2009 industrial production and export have declined more than GDP in those countries with average growth 3\%/month for industrial production. In the Federation of Bosnia and Herzegovina prices has declined also global demand reduced in the mining of metal ores by $50 \%$. Bulgaria was affected more in manufacture of basic metals declined by $58 \%$ and it has fallen $16 \%$ for output of basic and fabricated metals. Both Macedonian and Montenegro face declined in production in the mining and quarrying industry. It is not only the mining and metals industries but also textiles and clothing, motor vehicles and machinery and equipment production were all affected. However in December 2008, manufacturing output seemed to increase in Bosnia and in early 2009 industrial production has increased in almost all countries. 
Figura2. Industrial Production (\% change year-on-year)

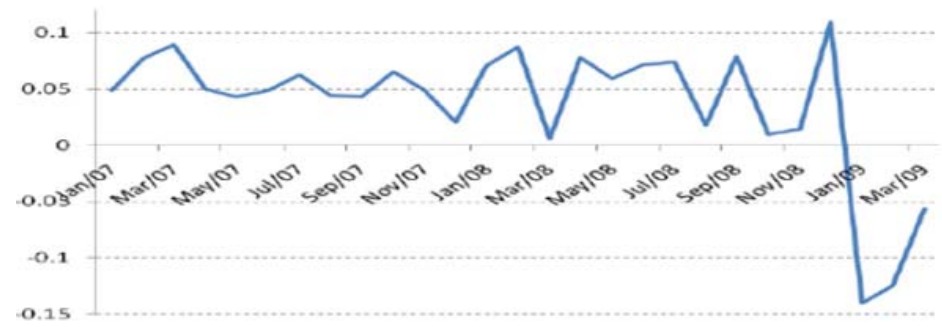

Figura3. Manufacturing Production Indices

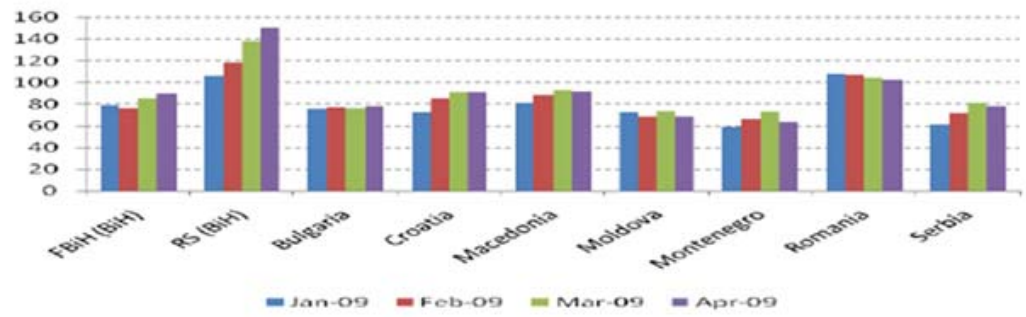

\subsection{Private consumption}

As all the other economic indicators, domestic consumer spending and private consumption have fallen as a result of weakened consumer confidence. In all countries retail trade has declined but for Croatia has been a dramatically decrease. The decline in Romania for retail trade was mostly evident in the sales of motor vehicles which were down by $32 \%$. In Moldova, growth in private consumption has declined from $8 \%$ in the half of 2008 to only $4.5 \%$ in 2009 and an important factor leading domestic consumption into downturn is the reduction of remittance inflows. In 2008, a current transfer has fallen for all countries except Montenegro, where they grew by $3 \%$, and Serbia.

In Bosnia and Herzegovina current transfers fell by $28 \%$, in Croatia by $11 \%$, in Moldova by $7 \%$, in Romania by $44 \%$ while the biggest fall in current transfers happened in Bulgaria and the Former Yugoslav Republic by 38\% and 46\% monthly.

Figura4. Retail Trade Turnover Indices

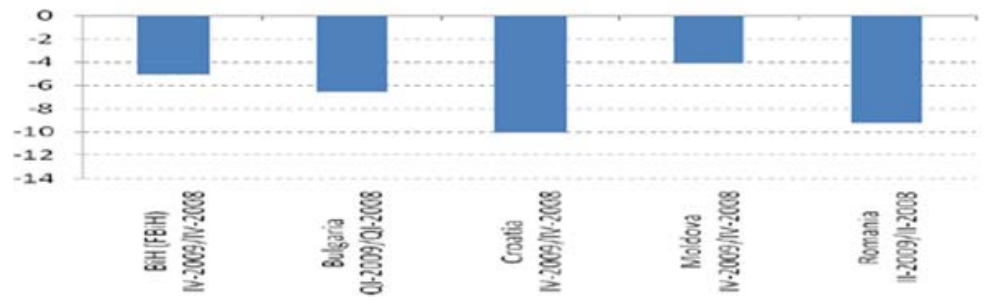

\subsection{Foreign direct investment}

The crisis affected negatively the FDI inflows by reducing them from EUR 7.6 billion to 4.8 billion inside of four months. FDI fell by $36 \%$ in Bulgaria, $20 \%$ in the Former Yugoslav Republic of Macedonia, 12\% in Montenegro and $9 \%$ in 
Romania. Also the countries like Albania, Croatia and Serbia faced the sharpest decline in FDI. The most affected from this crisis are manufacturing, food processing, apparel, chemicals and plastics, machinery, equipment and computers.

Figure 5. Total FDI in SEE

\subsection{Inflation}

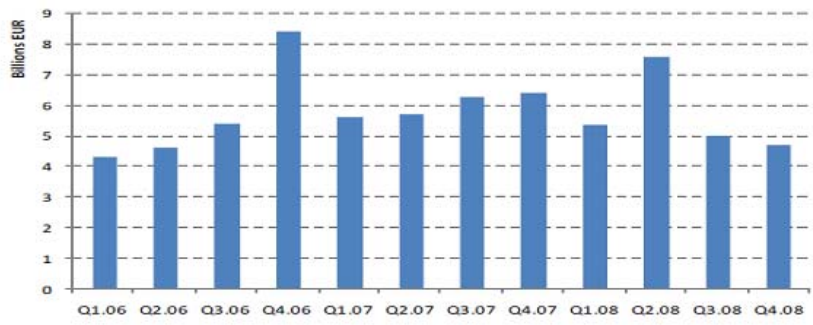

Before the 2008 recession, the SEE countries experienced higher rates of inflation around 10\% reflecting increases in the international price of oil and surging food prices but in the half of 2008 the slowdown in consumer consumption lead to weakness inflation in all countries. In Bulgaria, average consumer prices changed by $12 \%$ in $5 \%$. In Croatia, consumer prices came down to $2.9 \%$ while in Moldova fell significantly to $1 \%$ Albania, Bosnia and Herzegovina, the Former Yugoslav Republic of Macedonia and Romania have also seen falls in consumer price inflation.

Figure 6. Consumer Price Changes

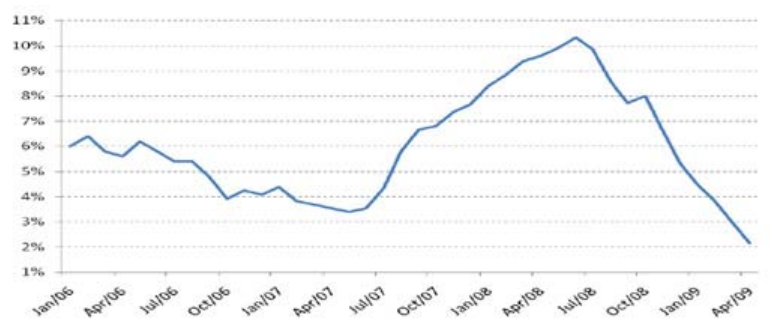

\subsection{Government accounts}

In the current years, few governments in the region have recorded a budget surplus. For 2007, as it seen in table, Bosnia and Herzegovina, Croatia, Moldova and Romania all recorded a budget deficit. Only Bulgaria enjoyed a budget surplus, of 3.8\% of GDP in2007 and in 2008 it estimated 3\% in order to expand fiscal stimulus policies.

Table 2. Government Budget Balance (\% GDP)

\begin{tabular}{|l|c|c|c|c|c|}
\hline \multicolumn{7}{|c|}{ Government budget balance (\% GDP) } \\
\hline & $\mathbf{2 0 0 4}$ & $\mathbf{2 0 0 5}$ & $\mathbf{2 0 0 6}$ & $\mathbf{2 0 0 7}$ & $\mathbf{2 0 0 8}$ \\
\hline Bosnia and Herzegovina & $-0.60 \%$ & $1.00 \%$ & $2.20 \%$ & $-0.30 \%$ & $-2.00 \%$ \\
\hline Bulgaria & $1.70 \%$ & $3.10 \%$ & $3.60 \%$ & $3.80 \%$ & $3.00 \%$ \\
\hline Croatia & $-2.70 \%$ & $-1.80 \%$ & $-0.70 \%$ & $0.20 \%$ & $-0.40 \%$ \\
\hline Macedonia (FYR) & $0.40 \%$ & $-0.80 \%$ & $-0.60 \%$ & $0.30 \%$ & $-0.80 \%$ \\
\hline Moldova & $0.40 \%$ & $2.00 \%$ & $-0.30 \%$ & $-0.30 \%$ & $-1.00 \%$ \\
\hline Romania & $-1.00 \%$ & $-0.80 \%$ & $-1.50 \%$ & $-3.20 \%$ & $-4.90 \%$ \\
\hline Serbia & $-2.04 \%$ & $2.31 \%$ & $2.47 \%$ & $0.97 \%$ & $-3.58 \%$ \\
\hline Average & $-\mathbf{0 . 5 5 \%}$ & $\mathbf{0 . 7 2} \%$ & $\mathbf{0 . 7 4 \%}$ & $\mathbf{0 . 2 1} \%$ & $-1.38 \%$ \\
\hline
\end{tabular}


For 2007 the Total external debt stock in the region was about 58\% of total SEE GDP and for 2008 is seemed to have increase $24 \%$ which predicts a higher interest and principal payments for many countries.

Table 3. External Debt Stock (\% GDP)

\begin{tabular}{|l|c|c|c|c|c|}
\hline \multicolumn{7}{|c|}{ External debt stock (\% GDP) } \\
\hline & $\mathbf{2 0 0 4}$ & $\mathbf{2 0 0 5}$ & $\mathbf{2 0 0 6}$ & $\mathbf{2 0 0 7}$ & $\mathbf{2 0 0 8}$ \\
\hline Albania & $18.53 \%$ & $16.18 \%$ & $16.83 \%$ & $15.85 \%$ & \\
\hline Bosnia and Herzegovina & $52.33 \%$ & $49.19 \%$ & $46.22 \%$ & $46.83 \%$ & $44.23 \%$ \\
\hline Bulgaria & $63.38 \%$ & $57.59 \%$ & $66.03 \%$ & $83.55 \%$ & $88.88 \%$ \\
\hline Croatia & $91.59 \%$ & $78.30 \%$ & $87.32 \%$ & $90.09 \%$ & $90.86 \%$ \\
\hline Moldova & $74.90 \%$ & $68.70 \%$ & $70.89 \%$ & $75.09 \%$ & $66.19 \%$ \\
\hline Macedonia (FYR) & $38.28 \%$ & $38.89 \%$ & $42.46 \%$ & $47.37 \%$ & $49.21 \%$ \\
\hline Romania & $39.18 \%$ & $39.51 \%$ & $44.92 \%$ & $45.98 \%$ & $46.38 \%$ \\
\hline Serbia & $57.50 \%$ & $58.96 \%$ & $61.69 \%$ & $63.10 \%$ & $69.02 \%$ \\
\hline SEE average & $\mathbf{5 4 . 4 6 \%}$ & $\mathbf{5 0 . 9 2 \%}$ & $\mathbf{5 4 . 5 4 \%}$ & $\mathbf{5 8 . 4 8 \%}$ & $\mathbf{6 4 . 9 7 \%}$ \\
\hline
\end{tabular}

\section{Conclusion}

There is a vast literature regarding the causality direction - finance-led growth, growth-driven finance and bi-directional between financial development and economic growth. In this paper we take into consideration the two crises, that of 1929 and that of 2008 and their impact in economy. Even if these two crises have similar impacts, they have also differences because of the 79 years gap between them. The main differences existing during these two crises in the economic aspect are listed as gold standard, economic policy, production pattern, the impact of WW I.

To sum up, the crisis of 2008 had negative impact in trade volume for SEE countries. Industrial production and private consumption had significantly decreased for this group of countries. Foreign direct investments, inflation rates and budget accounts had a lot of fluctuation after 2008. All these negative impacts have formed a closed cycle (negatively influencing) from financial sector to economic growth and vice-versa. Even though, it is important to underline that almost all the SEE countries had similar impacts, which means that they should adopt similar policies.

\section{References}

Acemoglu, D., F. Zilibotti, 1997, "Was Prometheus Unbound by chance? Risk Diversification and Growth," Journal of Political Economy, 105, 709-51.

Aghion, P, Dewatripont, M, and P. Rey (1999), 'Competition, Financial Discipline, and Growth', Review of Economic Studies, 66, 825852.

Allen F., and Douglas G., 1997. "Financial Markets, Intermediaries, and Intertemporal Smoothing," Journal of Political Economy, Vol. $105,523-546$.

Allen, F., 1990. The market for information and the origin of financial intermediation. Journal of Financial Intermediation 1, 3-30. and Economics 26 (June): 301-325.

Bagehot, W. Lombard street. Homewood, IL: Richard D. Irwin, [1873] 1962 Edition.

Bencivenga, V. R. and Smith, B. D. "Financial Intermediation and Endogenous Growth," Rev. Econ. Stud., Apr. 1991, 58(2), pp. 195209.

Bencivenga, V. R. and Smith, B. D. and Starr, R. M. "Transactions Costs, Technological Choice, and Endogenous Growth," J. Econ. Theory, Oct. 1995, 67(1), pp. 153-77.

Bencivenga, V. R. and Smith, B. D.. "Some Consequences of Credit Rationing in an Endogenous Growth Model," J. Econ. Dynam. Control, Jan.-Mar. 1993, 17(1/2), pp. 97-122.

Boyd, J. H. and Prescott, E. C. "Financial Intermediary-Coalitions," J. Econ. Theory, Apr. 1986, 38(2), pp. 211-32.

Boyd, J. H. and Smith, B. D. "How Good Are Standard Debt Contracts? Stochastic Versus Nonstochastic Monitoring in a Costly State Verification Environment," J. Bus., Oct. 1994, 67(4), pp. 539-61.

Coase, R. H. (1937) The Nature of the Firm, Economica, 4, 386-405.

De la Fuente, A., Marín, J.M., 1996. Innovation, bank monitoring, and endogenous financial development. Journal of Monetary Economics 38, 269--301.

Devereux, M. B. and Smith, G. W. "International Risk Sharing and Economic Growth," Int. Econ. Rev., Aug. 1994, 35(4), pp. 535-50.

Diamond, D. W. "Financial Intermediation and Delegated Monitoring," Rev. Econ. Stud., July 1984, 51(3), pp. 393-414.

Diamond, Douglas W. and Dybvig, P. H. "Bank Runs, Deposit Insurance, and Liquidity," J. Polit. Econ., June 1983, 91(3), pp. 401-19.

Fama, E. F. and Michael C. J. (1983b). "Separation of Ownership and Control." Journal of Law 
Gale, D. and Hellwig, M. "Incentive- Compatible Debt Contracts: The One- Period Problem," Rev. Econ. Stud., Oct. 1985, 52(4), pp. 647-63.

Greenwood, J. and Jovanovic, B. "Financial Development, Growth, and the Distribution of Income," J. Polit. Econ., Oct. 1990, 98(5,Pt.1), pp. 1076-1107.

Greenwood, J. and Smith, B. "Financial Markets in Development, and the Development of Financial Markets," J. Econ. Dynamics and Control, Jan. 1997, 21(1), pp. 145-81.

Grossman, S. J. and Miller, M. H. "Liquidity and Market Structure," J. Finance, July 1988, 43(3), pp. 617-33.

Grossman, S. J. and Stiglitz, J. E. "On the Impossibility of Informationally Efficient Markets," Amer. Econ. Rev., June 1980, 70(3), pp. 393-408.

Gurley, J. G. and Shaw, E. S. "Financial Aspects of Economic Development," Amer. Econ. Rev., Sept. 1955, 45(4), pp. $515-38$.

Hicks, J.. A theory of economic history. Oxford: Clarendon Press, 1969.

Holmstrom, B. and Tirole, J. "Market Liquidity and Performance Monitoring," J. Polit. Econ., Aug. 1993, 101(4), pp. 678-709.

Jensen, M. and Meckling, W. R. "Theory of the Firm: Managerial Behavior, Agency Costs, and Ownership Structure," J. Finan. Econ., Oct. 1976, 3(4), pp. 305-60.

Kashyap A.K., Rajan R.G., and Stein J.C., "Banks as Liquidity Providers: An Explanation for the Co-Existence of Lending and Deposit Taking," mimeo, University of Chicago, 1998

King, R. G. and Levine, Ross. "Financial Intermediation and Economic Development," in Financial intermediation in the construction of Europe. 1993a, pp. 156-89.

Kyle, A. S. "Market Structure, Information, Futures Markets, and Price Formation," in International agricultural trade: Advanced readings in price formation, market structure, and price instability.1984, pp. 45- 64.

Levine, R. "Stock Markets, Growth, and Tax Policy,"J. Finance, Sept. 1991, 46(4), pp. 1445-65.

Merton, R. C. "A Simple Model of Capital Market Equilibrium with Incomplete In- formation," J. Finance, July 1987, 42(3), pp. 483- 510.

Myers, S. C. and Majluf, N. S. "Corporate Financing and Investment Decisions When Firms Have Information That Investors Do Not Have," J. Finan. Econ., June 1984, 13(2), pp. 187-221.

Obstfeld, M. "Risk-Taking, Global Diversification, and Growth," Amer. Econ. Rev., Dec. 1994, 84(5), pp. 10-29.

Ramakrishnan, R. T. S., Thakor, A., 1984. Information reliability and a theory of financial intermediation. Review of Economic Studies July, 415-432.

Saint-Paul, G. "Technological Choice, Financial Markets and Economic Development," Europ. Econ. Rev., May 1992, 36(4), pp. 76381.

Schumpeter, J. A. Theorie der Wirtschaftlichen Entwicklung [The theory of economic development].Leipzig: Dunker \& Humblot, 1912;

Shleifer, A., Vishny R., 1997. The limits of arbitrage. Journal of Finance 52, 35-55.

Townsend, R. M. "Optimal Contracts and Competitive Markets with Costly State Verification," J. Econ. Theory, Oct. 1979, 21(2), pp. 265-93. 